\title{
ANALISIS STRATEGI SELF-REGULATED LEARNING MAHASISWA ILMU PENDIDIKAN UNIVERSITAS SARI MUTIARA INDONESIA DALAM PEMBELAJARAN BAHASA INGGRIS
}

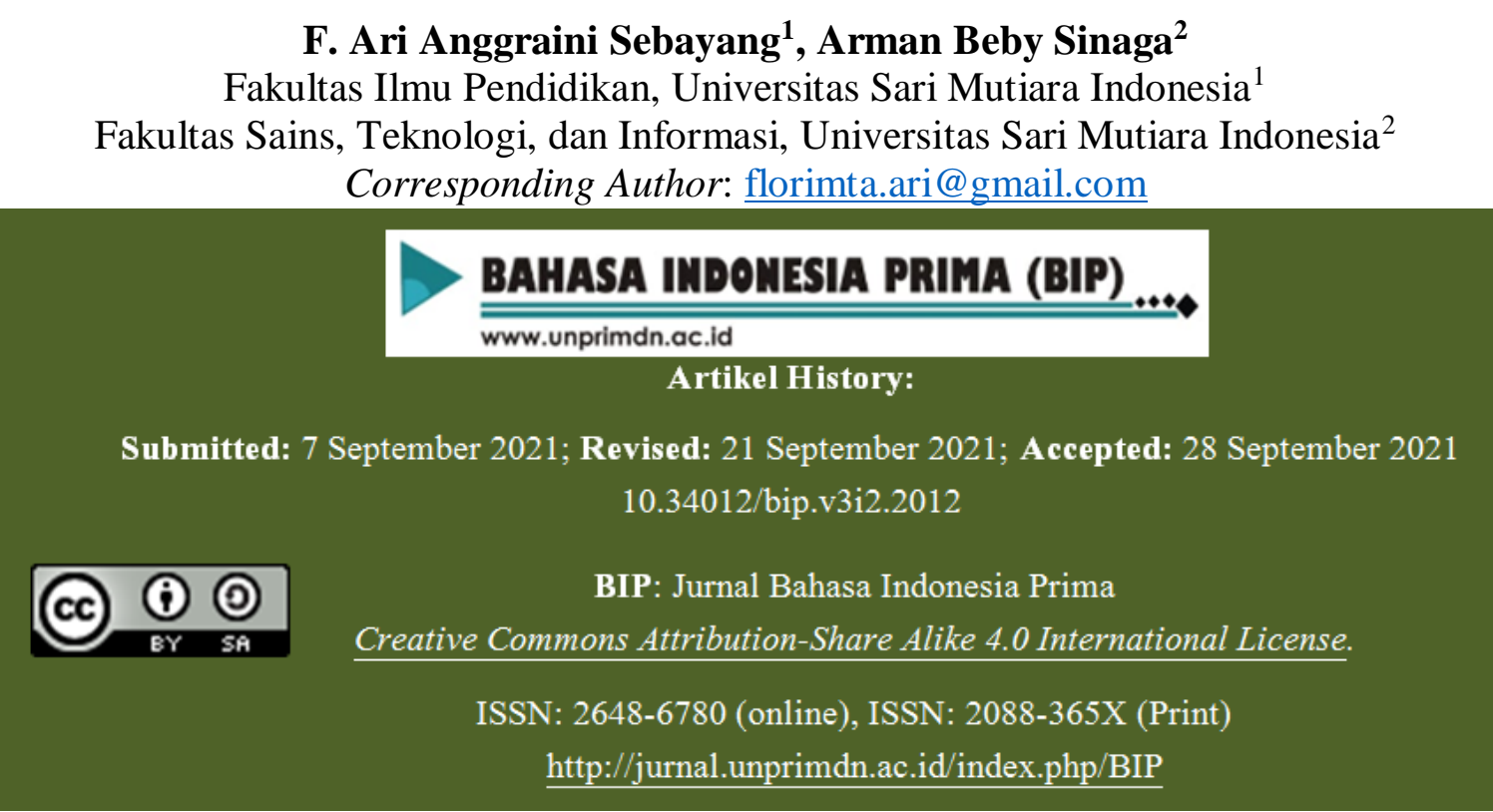

Abstrak-Kemajuan teknologi informasi ditambah dengan situasi pandemi saat ini memberikan kesempatan yang seluas-luasnya bagi mahasiswa untuk mengembangkan pembelajaran mandiri (self-regulated learning) yang aktif di luar kampus. Penelitian ini bertujuan untuk menganalisa strategi self-regulated learning (SRL) mahasiswa ilmu pendidikan Universitas Sari Mutiara Indonesia dalam pembelajaran bahasa Inggris. Metode penelitian yang digunakan pada penelitian ini adalah kuantitatif deskriptif. Populasi pada penelitian ini adalah mahasiswa Fakultas Ilmu Pendidikan di Universitas Sari Mutiara Indonesia yang berjumlah 314. Dengan menggunakan teknik random sampling, sebanyak 211 responden dijadikan sampel dalam penelitian ini. Pengumpulan data dilakukan dengan menggunakan kuesioner yang diadministrasikan dengan menggunakan Google Form. Kuesioner yang digunakan dalam penelitian ini terdiri atas 28 item yang bertujuan untuk mengukur strategi SRL yang terdiri atas beberapa variabel yaitu berbagi informasi (sharing information), kehadiran aktif (active presence), penggunaan dangkal dengan pemrosesan informasi terbatas (superficial use with limited information processing), perluasan dan pendalaman informasi (expansion and in-depth information), pengelolaan diri sendiri (personal management), evaluasi diri sendiri (self-evaluation), danpembelajaran kolaboratif (collaborative learning). Hasil analisis menunjukkan bahwa gambaran umum strategi SRL yang digunakan oleh mahasiswa responden pada penelitian ini masih cenderung rendah. Teknologi digital dalam memfasilitasi SRL masih cenderung digunakan untuk memperluas dan menperdalam informasi. Sementara strategi berbagi informasi (sharing information) masih cenderung rendah.

Kata kunci: self-regulated learning, pembelajaran aktif, english as foreign language

Abstract-The advancement of technology coupled with the current pandemic situation provide the widest opportunity for students to develop active self-regulated learning outside 
campus. This study aims to analyze the self-regulated learning (SRL) strategies of students of education major at Sari Mutiara Indonesia University in learning English. The research method used in this research was descriptive quantitative. The population in this study were 314 students of the Faculty of Education at Sari Mutiara University, Indonesia. By using a random sampling technique, 211 respondents were used asthe research sample. Data was collected using a questionnaire which was administered using Google Form. The questionnaire used in this study consisted of 28 items aimed at measuring the SRL strategies which consisted of several variables, namely sharing information, active presence, superficial use with limited information processing, expansion and in-depth information, personal management, self-evaluation, and collaborative learning. The results of the analysis show that the general description of the SRL strategies used by the respondent students in this study was relatively low. The digital technology in facilitating SRL was used to expand and deepen information. Meanwhile, the strategy of sharing information (information sharing) tends to be low.

Keywords: self-regulated learning, active learning, english as foreign language

\section{A. Pendahuluan}

Kemajuan teknologi, khususnya teknologi informasi, ditambah dengan siatuasi pandemi yang membatasi pergerakan siswa, secara tidak langsung, memaksa banyak siswa untuk beradaptasi dan menggunakan kesempatan berselancar di dunia maya dengan sebesarbesarnya.Dengan kemajuan teknologi khususnya teknologi informasi, banyak pakar yang berpendapat bahwa siswa menginginkan pengalaman belajar yang aktif dan didukung oleh berbagai media (McLoughlin and W.Lee, 2009). Pada saat ini, ada banyak sekali sumber belajar di Internet yang dapat memfasilitasi siswa dalam pembelajaran bahasa Inggris, tidak hanya aplikasi seperti Cake, Elsa, tetapi juga berbagai laman dank anal seperti British Council, Youtube, Google, Wikipedia. Dengan kemudahaan akses ke internet, siswa bisa belajar bahasa Inggris di mana saja dan kapan saja. Kemudahan akses pada berbagai sumber belajar dan informasi ini menjadi modal besar bagi siswa untuk dapat sukses dalam mengembangkan kemampuan berbahasa Inggris. Lebih lanjut lagi, Sulisworo, dkk.
(2020) berpendapat bahwa salah satu faktor kesuksesan siswa dalam menghadapi tantangan belajar di masa pandemi ini adalah dengan mengembangkan pembelajaran mandiri atau yang dikenal dengan self-regulated learning.

Menurut Zimmerman (1990) selfregulated learning bukanlah kemampuan mental atau keterampilan performa akademik tetapi sebuah proses yang mengarahkan siswa untuk mentransformasi kemampuan mental mereka menjadi keterampilan akademik. Siswa dengan self-regulated learningakan memandang pembelajaran sebagai sekumpulan aktivitas yang dilakukan secara proaktif yang didorong oleh perilaku dan motivasi untuk mencapai suatu tujuan belajar. Dalam self-regulated learning, siswa sadar akan kekuatan dan keterbatasan mereka dalam belajar. Kesadaran dan dorongan untuk mencapai tujuan belajar tertentu inilah yang menjadikan siswa menjadi pembelajar seumur hidup yang menjadi tujuan penting dalam dunia pendidikan. 
Melalui penelitian yang dilakukan terhadap mahasiswa di beberapa universitas di Andalusia, Yot-Domínguez \& Marcelo (2017) menemukan bahwa teknologi digunakan untuk memfasilitasi siswa dalam berbagai kegiatan yang mampu meningkatkan pembelajaran selfregulated mereka, di antaranya membaca, mengklasifikasikan, menggunakan, atau berbagi informasi kepada orang lain. Selain itu, $X$ juga menemukan bahwa teknologi membantu pembelajar untuk belajar dengan level kesengajaan (intentionality) yang lebih tinggi dan kompleksitas kognitif (cognitivecomplexity), seperti monitoring, self-assessment atau personal management. Berbagai kegiatan ini tentunya akan mampu memfasilitasi siswa untuk menjadi lebih sukses dalam pembelajaran mereka karena siswa secara rutin memastikan dan memonitor setiap pemahaman yang mereka peroleh.

Penelitian ini berusaha untuk mengeksplorasi strategi pembelajaran mandiri (self-regulated learning) mahasiswa dalam belajar dan mengembangkan kemampuan bahasa Inggris dengan menggunakan bantuan teknologi digital. Pembelajaran mandiri saat ini menjadi sangat penting karena pembelajaran jenis ini mengajarkan siswa untuk tidak lagi bergantung dan mengandalkan guru sebagai sumber utama informasi dan pengetahuannya. Tetapi lebih dari pada itu, pembelajaran mandiri melatih siswa untuk menjadi pembelajar seumur hidup (life-long learning). Siswa yang menerapkan pembelajaran mandiri tidak hanya memotivasi diri mereka sendiri untuk belajar, tetapi mereka juga mampu menetapkan target capaian dari setiap pembelajaran yang dilakukan, memonitor pembelajaran, dan mengevaluasi apa yang telah mereka pelajari. Oleh karena itu, penelitian ini secara umum akan menganalisis profil pembelajaran mahasiswa dalam pembelajaran bahasa Inggris secara mandiri dengan menggunakan bantuan teknologi informasi.

\section{B. Metode Penelitian}

Penelitian ini merupakan penelitian kuantitatif deskriptif yang bertujuan untuk menganalisa penggunaan teknologi digital yang dilakukan oleh mahasiswa untuk memfasilitasi pembelajaran bahasa asing secara mandiri. Adapun responden penelitian ini adalah mahasiswa Fakultas Ilmu Pendidikan Universitas Sari Mutiara Indonesia tahun akademik 2020/2021 dengan jumlah populasi 314. Dengan menggunakan teknik random sampling sebanyak 211 responden dijadikan sebagai sampel dalam penelitian ini. Pengumpulan data dilakukan dengan mengadministrasikan survey yang dilakukan secara daring dengan menggunakan Google Form.Instrumen yang digunakan merupakan adaptasi dari kuesioner yang dikembangkan oleh YotDomínguez \& Marcelo (2017) untuk mengetahui profil strategi SRL yang terdiri atas variabel share information, active presence, documentation and classification, superficial use with limited information processing, expansion and indepth information, personal management, self-evaluation, dan collaborative learning. Kuesioner ini digunakan setelah dilakukan uji reliabilitas dan validitas dengan nilai Cronbach Alpha $=0.91$.

\section{Hasil Dan Pembahasan}

Strategi Self-Regulated Learning dalam pembelajaran bahasa Inggris

Tabel 1. Nilai rata-rata dan standar deviasi variabel Berbagi Informasi (share information) 


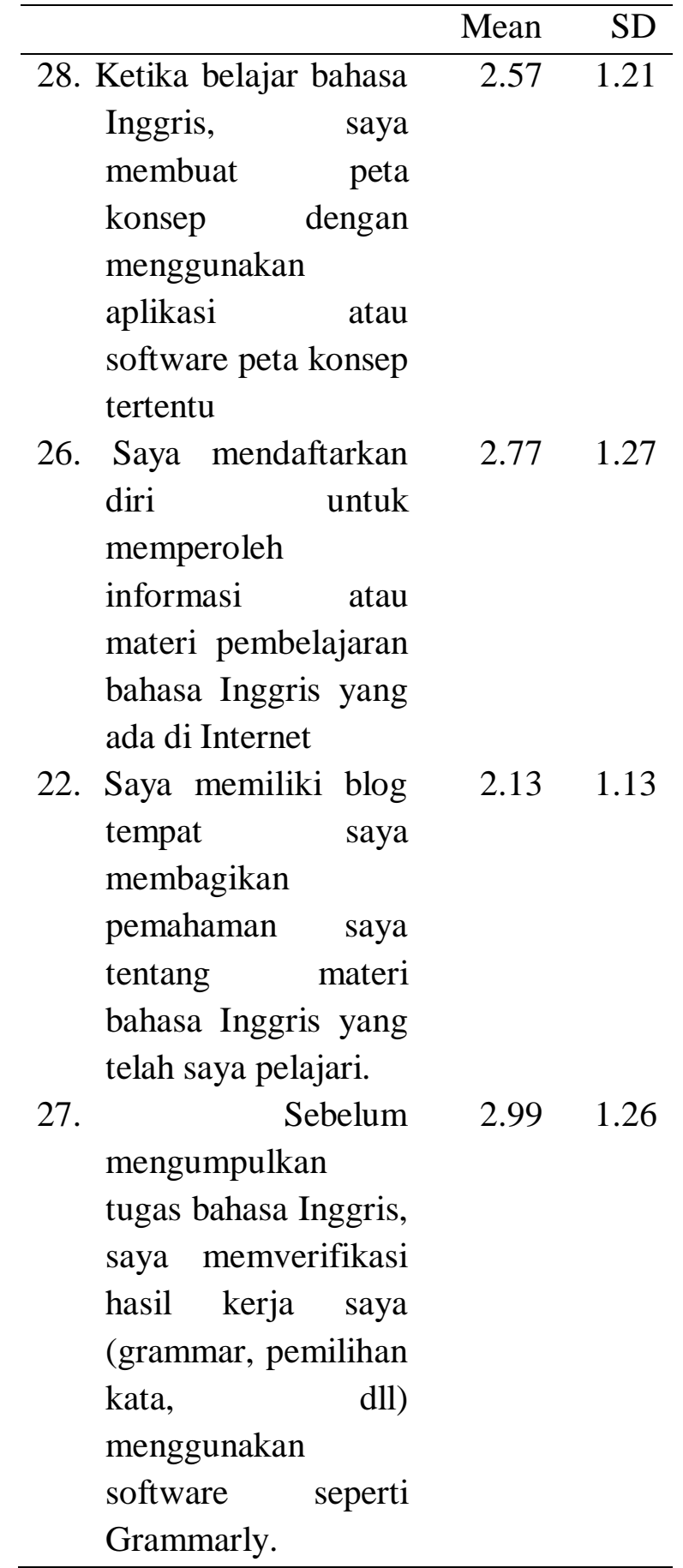

Tabel 1 menunjukkan data nilai ratarata dan standar deviasi variabel berbagi informasi (share information) yang digunakan responden dalam belajar bahasa Inggris. Dapat dilihat bahwa rata-rata nilai yang diperoleh relatif rendah dengan nilai terendah adalah pada kepemilikan blog untuk membagikan pemahaman tentang materi bahasa Inggris yang telah dipelajari, yaitu sebesar $M=2.13$. Sementara itu, nilai rata-rata yang tertinggi pada variabel
Berbagi Informasi terlihat pada poin penggunaan software untuk memverifikasi hasil kerja sebelum pengumpulan tugas, yaitu sebesar $\mathrm{M}=2.99$. Menurut YotDomínguez and Marcelo (2017), berbagi informasi (share information) merupakan salah satu strategi yang dilakukan oleh siswa yang menerapkan self-regulated learning dalam pembelajaran sehari-hari. Siswa yang menunjukkan SRL yang tinggi pada umumnya akan membagikan apa yang mereka telah kerjakan dalam proses pembelajaran mereka dan mengambil resiko terhadap kritikan yang mungkin diterima dari pembaca.

Tabel 2. Nilai rata-rata dan standar deviasi variabel Kehadiran Aktif (Active Presence)

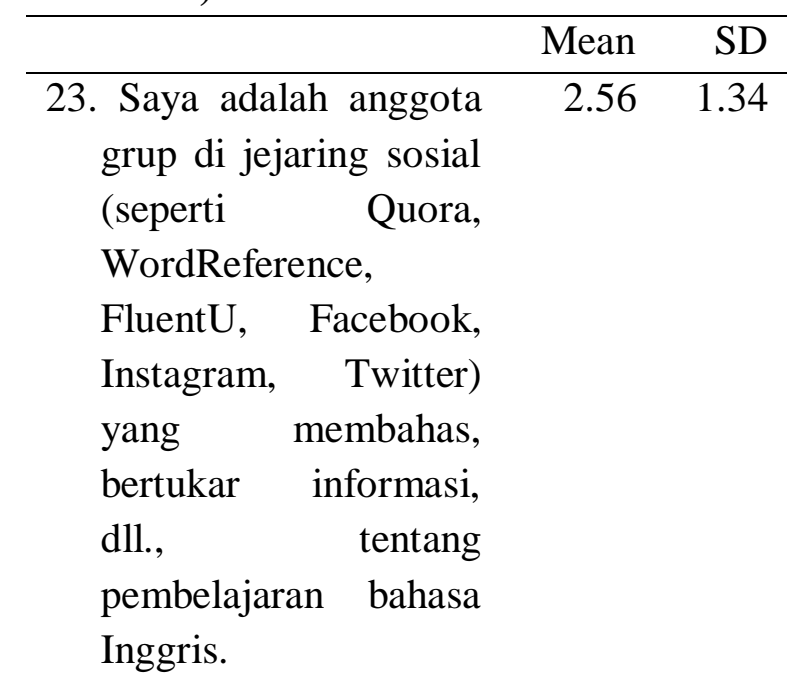

1. Saya mendiskusikan $3.05 \quad 1.16$ topik yang didiskusikan oleh dosen pada mata kuliah Bahasa Inggris (misal grammar, vocabulary, reading) pada forum diskusi di media social seperti Twitter, Facebook dan media sosial lain yang sejenis.

25. Saya membagikan $2.68 \quad 1.24$ 
gambar-gambar di

Instagram, Pinterest,

Facebook, dan

platform sejenis,

tentang kerja praktek

yang dilakukan untuk

mata pelajaran bahasa

Inggris.

$\begin{array}{lrrr}\text { 24. Saya } & \begin{array}{r}\text { mencari } \\ \text { terkait }\end{array} & 3.16 & 1.12 \\ \text { informasi } & & \end{array}$

konten bahasa Inggris,

berita, dll. yang

didistribusikan di

jejaring sosial.

Tabel 2 memberikan gambar nilai ratarata dan standar deviasi yang diperoleh pada variabel Kehadiran Aktif (active presence). Pada variabel ini, dapat kita lihat bahwa nilai rata-rata berada pada rentang moderat dan rendah. Nilai rata-rata tertinggi pada variabel ini ditunjukkan pada poin pencarian konten bahasa Inggris yang dilakukan oleh siswa pada jejaring sosial, dengan $\mathrm{M}=3.16$. Sementara, nilai rata-rata terendah pada variabel ini ditunjukkan pada poin kehadiran pada platform jejaring sosial untuk berdiskusi, membahas, dan bertukar pikiran tentang pembelajaran Bahasa Inggris, dengan $\mathrm{M}=$ 2.56, $\mathrm{SD}=1$ 1.16. Hal ini menunjukkan bahwa kehadiran siswa pada platform jejaring sosial masih terfokus pada pencarian informasi, belum pada tahap pemanfaatan jejaring sosial untuk mendiskusikan dan berbagi informasi tentang pembelajaran bahasa Inggris.

Yot-Domínguez and Marcelo (2017) menyatakan kehadiran aktif siswa dalam pelaksanaan SRL bukan hanya pada laman-laman yang memberikan informasi terkait pembelajaran bahasa Inggris, tetapi juga pada ruang atau platform untuk dapat berinteraksi dengan komunitas tertentu untuk membentuk pembelajaran sosial (construct learning). Interaksi yang dilakukan pada jejaring sosial untuk mendukung pembelajaran Bahasa Inggris juga berkaitan dengan collaborative learning untuk secara bersama-sama mendiskusikan, berbagi ide atau gagasan, perasaan, dan refleksi yang diperoleh bukan hanya dari pembelajar tetapi juga dari ahli. Variabel kehadiran aktif juga memberikan gambaran strategi belajar aktif yang ditunjukkan oleh siswa untuk memanfaatkan teknologi dan ruang-ruang terbuka yang tersedia untuk memfasilitasi pembelajaran dan mengembangkan kemampuan berbahasa Inggris.

Tabel 3 Nilai rata-rata dan standar deviasi variabel penggunaan pemrosesan informasi terbatas (superficial use with limited information processing)

\begin{tabular}{lrr}
\hline & Mean & SD \\
\hline 9. Saya menggunakan & 3.68 & 1.07 \\
Google atau Wikipedia & & \\
ketika saya perlu & & \\
mengklarifikasi & & \\
penggunaan struktur & & \\
bahasa (grammar) atau & & \\
konsep terkait. &
\end{tabular}

Tabel 3 menunjukkan nilai rata-rata dan standar deviasi yang diperoleh pada variabel penggunaan software untuk memfasilitasi keterbatasan informasi yang dimiliki oleh siswa. Berdasarkan analisis validitas konten, poin 8 'saya menggunakan penerjemah bahasa Indonesia - bahasa Inggris (sebaliknya) yang berbasis web untuk mencari tahu kata-kata yang tidak saya ketahui artinya seperti Google Translate atau kamus daring lainnya' memperoleh nilai $r=0.175$ atau lebih rendah daripada nilai $r$ tabel= 0.3061 , sehingga poin ini dinyatakan tidak valid dan tidak diikutsertakan dalam 
kuesioner. Hal inilah yang menyebabkan variabel penggunaan software atau laman tertentu untuk memfasilitasi keterbatasan informasi hanya terdiri atas 1 poin saja. Data pada Tabel 3 menunjukkan bahwa nilai rata-rata penggunaan software atau laman tertentu untuk memfasilitasi keterbatasan informasi pada siswa relatif tinggi, $\mathrm{M}=3.68$.

Hasil yang diperoleh pada penelitian ini sejalan dengan Yot-Domínguez and Marcelo (2017) yang juga menemukan strategi SRL yang dilakukan oleh mahasiswa responden di Andalusia, khususnya pada penggunaan Wikipedia, Google atau sumber serupa lainnya untuk mengklarifikasi konsep, relatif tinggi, dengan $M=3.85$. Penggunaan sumbersumber berbasis web yang tersedia di internet menunjukkan kemandirian belajar yang tinggi yang ditunjukkan oleh siswa dalam memfasilitasi pembelajaran. Lim (2009) menambahkan kecenderungan yang penggunaan Wikipedia atau Google dilakukan oleh siswa ketika mereka membutuhkan informasi yang instan untuk memfasilitasi keterbatasan yang mereka miliki. Akan tetapi, penggunaan sumbersumber instan tersebut hanya mampu memberikan informasi yang terbatas dan hanya memfasilitasi siswa untuk proses berpikir rendah (low-level of information processing).

Tabel 4. Nilai rata-rata dan standar deviasi variabel perluasan dan informasi mendalam (expansion and indepth information)

\begin{tabular}{lrr}
\hline & Mean & SD \\
\hline 3. Ketika belajar Bahasa & 3.59 & 1.03 \\
Inggris, saya mencari & & \\
sumber belajar & & \\
multimedia atau & & \\
presentasi yang berisi & & \\
\hline
\end{tabular}

konten atau materi

yang sedang saya pelajari (Slideshare, Pinterest, Youtube, dan platform sejenis lainnya).

5. Ketika belajar Bahasa $3.48 \quad 1.04$ Inggris, saya mencari berbagai video yang berkaitan dengan materi yang sedang saya pelajari di Youtube, Vimeo, atau media sosial berbasis video lainnya yang sejenis.

10. Saya mengikuti $3.34 \quad 1.06$ saluran video Youtube dimana terdapat video-video yang berhubungan dengan topik bahasa Inggris yang saya pelajari.

11. Saya mengikuti blog $2.86 \quad 1.17$ oleh para ahli yang menerbitkan kontenkonten tentang pembelajaran Bahasa Inggris.

Tabel 4 memberikan gambaran nilai rata-rata dan standar deviasi pada variabel yang menunjukkan strategi yang dilakukan siswa untuk memperluas dan memperdalam informasi yang dimiliki selama pembelajaran bahasa Inggris. Dari tabel tersebut, dapat dilihat bahwa secara umum nilai rata-rata pada variabel berada pada rentang moderat dan rendah. Nilai rata-rata terendah ditunjukkan pada poin mengikuti blog para ahli yang menerbitkan konten-konten tentang pembelajaran bahasa Inggris, dengan $\mathrm{M}=2.86$. Sementara poin kegiatan mencari sumber 
belajar multimedia pada Youtube dan platform sejenis menunjukkan nilai ratarata tertinggi, dengan $M=3.59$. Jika nilai rata-rata pada variabel ini dibandingkan, maka dapat dilihat bahwa pada umumnya, responden mahasiswa pada penelitian ini masih cenderung hanya melakukan pencarian secara acak pada internet, tetapi belum secara rutin mengikuti satu saluran atau blog tertentu yang dijadikan rujukan untuk memfasilitasi pembelajaran bahasa Inggris mereka.

Variabel perluasan dan pendalaman informasi, secara umum, dapat menggambarkan langkah proaktif yang dilakukan oleh siswa dalam memfasilitasi pembelajaran bahasa Inggris. Hal ini juga memberikan gambaran kemandirian yang ditunjukkan oleh siswa untuk mengembangkan kemampuan bahasa Inggris mereka. Siswa yang menunjukkan SRL yang tinggi, pada umumnya akan menggunakan fasilitas yang ada seperti teknologi internet untuk memperdalam pengetahuan dan mempertajam konsepkonsep bahasa Inggris yang mereka miliki.

Tabel 5. Nilai rata-rata dan standar deviasi variabel pemantauan dan umpan balik (monitoring and feedback)

\begin{tabular}{lrrr}
\hline & & Mean & SD \\
\hline 2. Saya merekam & 2.84 & 1.15 \\
penjelasan dosen/ guru & & \\
ketika menjelaskan & & \\
materi perkuliahan & & \\
Bahasa Inggris dengan & & \\
menggunakan ponsel & & \\
pintar saya. & & \\
6. Ketika belajar Bahasa & 2.97 & 1.23 \\
Inggris, & & \\
mendengarkan podcast & & \\
yang berisi materi & & \\
Bahasa Inggris yang & \\
sedang saya pelajari di & \\
\hline
\end{tabular}

Podcast, Spotify, Joox,

iTunes atau aplikasi podcast sejenis lainnya.

7. Saya merekam sendiri $3.05 \quad 1.11$ materi yang sedang saya pelajari supaya bisa saya gunakan lagi ketika saya belajar di kemudian hari.

12. Saat mempersiapkan presentasi, ujian praktik atau evaluasi Bahasa Inggris sejenis, saya merekam diri saya menggunakan

perangkat genggam (audio recorder atau video recorder).

Tabel 5 menunjukkan nilai rata-rata yang diperoleh responden pada pelaksanaan strategi SRL pemantauan dan umpan balik (monitoring and feedback). Data pada Tabel 5 menunjukkan bahwa penggunaan teknologi digital untuk memantau dan memberikan umpan balik terhadap pembelajaran bahasa Inggris yang telah dilakukan pada rentang moderat dan rendah. Nilai terendah pada variabel ini ditunjukkan pada poin penggunaan ponsel pintar untuk merekam penjelasan dosen ketika menjelaskan materi di dalam kelas, dengan $\mathrm{M}=2.84$. Sementara poin yang menunjukkan nilai rata-rata tertinggi terdapat pada 'saya merekam sendiri materi yang sedang saya pelajari supaya saya bisa gunakan lagi ketika saya belajar di kemudian hari', dengan $\mathrm{M}=3.05$.

Tabel 6. Nilai rata-rata dan standar deviasi variabel manajemen personal (personal management)

\begin{tabular}{|c|c|c|}
\hline & Mean & SD \\
\hline 13. Saya menggunakan & 2.64 & 1.24 \\
\hline program & & \\
\hline
\end{tabular}




\section{Google Calendar, \\ EverNote atau \\ platform pengatur \\ jadwal sejenis untuk \\ membantu saya \\ mengatur jadwal saya \\ belajar Bahasa \\ Inggris.}

14. Saya mengunduh

(mendowload)

materi-materi yang

dapat membantu saya

dalam belajar Bahasa

Inggris dari sumber

belajar tidak berbayar

seperti British

Council atau laman

sejenis.

15. Saya mengaktifkan notifikasi untuk menerima informasi terbaru tentang materi-materi belajar

Bahasa Inggris dari laman yang saya ikuti.

16. Saya menggunakan aplikasi tertentu (seperti Elsa, Cake, dan aplikasi belajar Bahasa Inggris lainnya) untuk membantu saya belajar dan melatih kemampuan Bahasa Inggris saya.

Tabel 6 menunjukkan data nilai ratarata responden dalam mengelola diri mereka sendiri selama pembelajaran bahasa Inggris menggunakan strategi SRL. Data pada tabel 6 memberikan gambaran bahwa nilai rata-rata secara umum pada variabel pengelolaan diri sendiri pada rentang moderat dan rendah. Nilai rata-rata terendah ditunjukkan pada poin 13 'Saya menggunakan program seperti Google Calendar, EverNote atau platform pengatur jadwal sejenis untuk membantu saya mengatur jadwal saya belajar Bahasa Inggris', dengan $M=2.64$. Sementara, nilai rata-rata tertinggi ditunjukkan pada poin 14 'Saya mengunduh (mendowload) materi-materi yang dapat membantu saya dalam belajar Bahasa Inggris dari sumber belajar tidak berbayar seperti British Council atau laman sejenis', dengan $M=3.19$. Nilai rata-rata yang relatif rendah pada penggunaan software atau aplikasi yang mengatur jadwal menunjukkan bahwa responden belum sepenuhnya memiliki jadwal tertentu dalam pembelajaran mereka. Penemuan ini juga sejalan dengan Yot-Domínguez and Marcelo (2017) yang juga menemukan penggunaan aplikasi atau jadwal yang rendah dengan $\mathrm{M}=2.22$.

Menurut Yot-Domínguez and Marcelo (2017), strategi pengelolaan diri sendiri ini berkenaan dengan usaha yang dilakukan siswa dalam mengatur jadwal belajar dan pengelolaan informasi. Lebih lanjut lagi, strategi ini menunjukkan kebutuhan siswa dalam mengakses informasi yang mampu membantu mereka dalam belajar dan menyelesaikan berbagai tugas akademik dengan cara yang paling effesien dan efektif.

Tabel 7. Nilai rata-rata dan standar deviasi variabel evaluasi diri (self evaluation)

\begin{tabular}{lrr}
\hline & Mean & SD \\
\hline 17. Saya mencari latihan- & 3.27 & 1.08 \\
latihan yang tersedia & & \\
di Internet untuk & & \\
evaluasi diri dan saya & & \\
menggunakannya & & \\
untuk mempersiapkan & & \\
\hline
\end{tabular}




\begin{tabular}{lll}
\hline ujian bahasa Inggris. & & \\
18. Saya membuat sampel & 2.58 & 1.29 \\
ujian online (dengan & & \\
menggunakan \\
ExamTime, Google \\
Forms atau platform \\
sejenis) $\quad$ dan \\
membagikannya \\
dengan teman sekelas \\
saat mempersiapkan \\
ujian bahasa Inggris.
\end{tabular}

Tabel 7 menunjukkan usaha-usaha yang dilakukan oleh siswa dalam melaksanaan SRL variabel evaluasi diri pada pembelajaran bahasa Inggris. Berdasarkan data pada Tabel 7, dapat dilihat bahwa siswa lebih sering mencari berbagai latihan yang tersedia di internet untuk mengevaluasi apa yang telah mereka pelajari, dengan $\mathrm{M}=3.27$. Sementara itu, data menunjukkan usaha yang dilakukan siswa untuk membuat sampel ujian online dengan menggunakan berbagai laman atau software masih relatif rendah, $\mathrm{M}=2.58$.

Tabel 8. Nilai rata-rata dan standar deviasi variabel pembelajaran kolaboratif (collaborative learning)

\begin{tabular}{lrr}
\hline & Mean & SD \\
\hline 4. Saya membagikan & 2.82 & 1.19 \\
materi belajar yang & & \\
berkaitan dengan & & \\
Bahasa Inggris dengan & & \\
teman sekelas saya & & \\
menggunakan & & \\
Dropbox, Google+, & & \\
atau platform berbagi & & \\
sejenis lainnnya. & & \\
19. Saya menghasilkan & 2.40 & 1.29 \\
karya kolaboratif & & \\
menggunakan alat & \\
seperti Wiki, Google & \\
Drive dan platform & \\
\hline
\end{tabular}

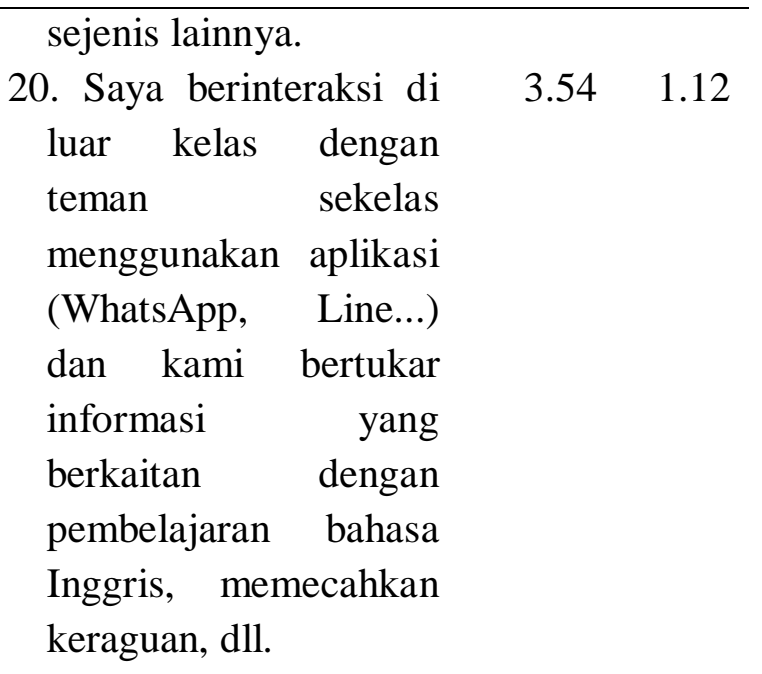

21. Saya berkomunikasi dengan teman sekelas saya melalui konferensi video (Skype, Google Talk, Zoom, Google Meet atau platform sejenis) untuk memecahkan atau mendiskusikan topik yang berkaitan dengan bahasa Inggris.

Tabel 8 menunjukkan nilai rata-rata siswa dalam mengimplementasikan pembelajaran kolaboratif sebagai usaha dalam pembelajaran mandiri (SRL) pada pembelajaran bahasa Inggris. Berdasarkan data yang ditampilkan pada tabel tersebut, nilai rata-rata terendah ditunjukkan pada pembuatan karya kolaboratif menggunakan alat seperti Wiki, Google Drive atau platform sejenisnya, dengan $M=2.40$. Sementara itu, nilai rata-rata tertinggi ditunjukkan pada interaksi di luar kelas dengan teman sekelas dengan menggunakan aplikasi, seperti WhatsApp atau Line, untuk bertukar informasi yang berkaitan dengan pembelajaran bahasa Inggris dengan $M=3.54$. Hasil temuan ini juga sejalan dengan Yot-Domínguez and Marcelo (2017) yang menemukan nilai rata-rata yang tinggi pada penggunaan teknologi untuk berdiskusi perihal materi 
BIP: Jurnal Bahasa Indonesia Prima Vol. 3, No. 2, 2021, September 2021, PP.

pelajaran dengan teman sekelas di luar jam pelajaran dengan $\mathrm{M}=4.59$.

\section{Kesimpulan}

Berdasarkan data nilai rata-rata yang ditampilkan pada tabel-tabel di atas, dapat dilihat gambaran secara umum perihal penggunaan berbagai strategi SRL yang masih relatif rendah pada mahasiswa penelitian ini dalam memfasilitasi pembelajaran Bahasa Inggris di luar jam pelajaran di kampus. Jika diperhatikan, penggunaan teknologi dalam memfasilitasi pembelajaran masih difokuskan pada usaha mencari informasi. Berbagai kegiaran untuk saling berdiskusi, mengelola diri sendiri, dan menghasilkan karya tertentu sebagai usaha untuk mengevaluasi apa yang telah dipelajari dan rutin melakukan pembelajaran juga masih relatif rendah.

\section{Daftar Pustaka}

Bernacki, M.L., Aguilar, A.C., \& Byrnes, J.P. (2011). Self-regulated learning and technology-enhanced learning environments: An opportunitypropensity analysis. In G. Dettori, \& D. Persico (Eds.). Fostering selfregulated learning through ICT, (pp 1-26). Hersey, PA: IGI Global Publishers.

Lim, S. (2009). How and why do College students use Wikipedia? Journal of the American Society for Information Science and Technology, 60(11), 2189-2202. doi:10.1002/asi.21142.

McLoughlin, C., \& Lee, M.J.W. (2010). Personalised and self regulated learning in the Web 2.0 era: International exemplars of innovative pedagogy using social software. Australasian Journal of
Educational Technology, 26(1). https://doi.org/10.14742/ajet.1100.

Oxford, R. (2016). Teaching and researching language learning strategies: Self-regulation in context ( $\left.2^{\text {nd }} e d\right)$. Routledge.

Schneckenberg D., Ehlers, U., \& Adelsberger, H. (2011). Web 2.0 and competence-oriented design of learning. Potentials and implications for higher education. British Journal of Educational Technology, 42(5), 747-762. doi:10.1111/j.14678535.2010.01092.x.

Sulisworo, D., dkk. (2020). Students' selfregulated learning (SRL) profile dataset measured during Covid-19 mitigation in Yogyakarta, Indonesia. Data in Brief. https://doi.org/10.1016/j.dib.2020.1 06422.

Viberg, O., Wasson, B., \& KukulsaHulme, A. (2020). Mobile-assisted language learning through learning analytics for self-regulated learning (MALLAS): A conceptual framework. Australasian Journal of Educational Technology, 36(6).

Yot-Domínguez, C., \& Marcelo, C. (2017). University students' selfregulated learning using digital technologies. International Journal of Educational Technology in Higher Education, 14(38). DOI 10.1186/s41239-017-0076-8.

Zimmerman, B.J. (1990). Self-regulated learning and academic achievement: an overview. 
BIP: Jurnal Bahasa Indonesia Prima Vol. 3, No. 2, 2021, September 2021, PP.

Educational Psychologist. DOI:

10.1207/s15326985ep2501_2

Analisis Strategi Self-Regulated Learning Mahasiswa IImu 